\title{
LOW COST ULTRASONIC VAPOUR PYROLYSIS METHOD FOR BORON DOPED CADMIUM SULPHIDE THIN FILM
}

\author{
DINESH BOROLE ${ }^{1}$, KUMUDINI BOROLE ${ }^{2}$, G. B. K. S. PRASAD ${ }^{3}$ \& P. RAJARAM ${ }^{4}$ \\ ${ }^{1,3}$ School of Studies in Biochemistry, Jiwaji University, Gwalior, MadhyaPradesh, India \\ ${ }^{2}$ Department of Biochemistry, Jawaharlal Nehru Medical College, Datta Meghe Institute of Medical Sciences, \\ Sawangi(meghe), Wardha, Maharashtra, India \\ ${ }^{4}$ School of Studies in Physics, Jiwaji University, Gwalior, MadhyaPradesh, India
}

\begin{abstract}
In this work, low cost Ultrasonic vapour pyrolysis technique was used to obtain boron doped Cadmium sulfide (CdS) thin films. The structure and morphology of obtained thin films were characterized by X-ray diffraction (XRD), scanning electron micrograph (SEM), energy dispersion analysis of X-rays (EDAX) and conductivity was measured by ohm meter in presence of sun light.The optical properties of the samples were studied using UV-Visible spectroscopy. Boron doped cadmium sulphide thin films showed decreased resistivity. It was concluded that ultrasonic vapour pyrolysis gives boron doped CdS thin film of very high quality for solar cell window layer.

KEYWORDS: Ultrasonic Vapour, Boron Doped, Cadmium Sulfide, Pyrolysis, Thin Film \& Solar Cell
\end{abstract}

Received: Sep 13, 2019; Accepted: Oct 03, 2019; Published: Nov 23, 2019; Paper Id.: IJNADEC20191

\section{INTRODUCTION}

The cadmium sulfide (CdS) is a unique n-type semiconductor having direct band gap of $2.42 \mathrm{eV}$ with many excellent physical and chemical properties. It has many promising applications in many fields including photochemical catalysis, gas sensor, detectors for laser and infrared, solar cells, various luminescence devices, optoelectronic devices and so on (Lekha Verma et al. ). It is used as window layer materials in solar cells.

There are many methods used by various researchers to develop CdS thin films (Lee et al. 2003), some are, spray pyrolysis (Meshram et al. 2012), electrode position (Sasikala et al. 1997), chemical bath method (Reddy et al. 2013, Wug-Dong Park et al. 2012), vacuum deposition (Zanje et al. 2015) and many more. In most of the solution based methods, complexing agents were used to control the precipitation of cadmium sulphide. Some of the complexing agents are ammonia, ethanol amine, diethanolamine, triethanolamine, EDTA, citric acid, tartaric acid.

Ultrasonic vapour pyrolysis is a simple technique that enables the growth of high quality thin film. In our present work, an attempt was made to deposit the boron doped cadmium sulphide thin films using low cost commonly used ultrasonic vapourizer. Boron doping has shown higher electron mobility (Hagiwara et al. 2001).

\section{MATERIALS AND METHODS}

\subsection{Experimental Setup}

Automated ultrasonic vapour pyrolysis system was setup as shown in figure 1. It consists of ultrasonic vapourizer, vapour delivery system, framework to move in XY direction, temperature controlled heating platform. Ultrasonic 
vapour generator was made out of peizo electric crystal of 1.6 MHz. Peizo electric crystal and supporting electronic kit were purchased from the market. Ultrasonic vapour generator converts solution into fine mist. These fine mist particles are carried by air. PVC pipe does not react with the vapors at room temperature. Filtered compressed air was made available using portable air compressor.

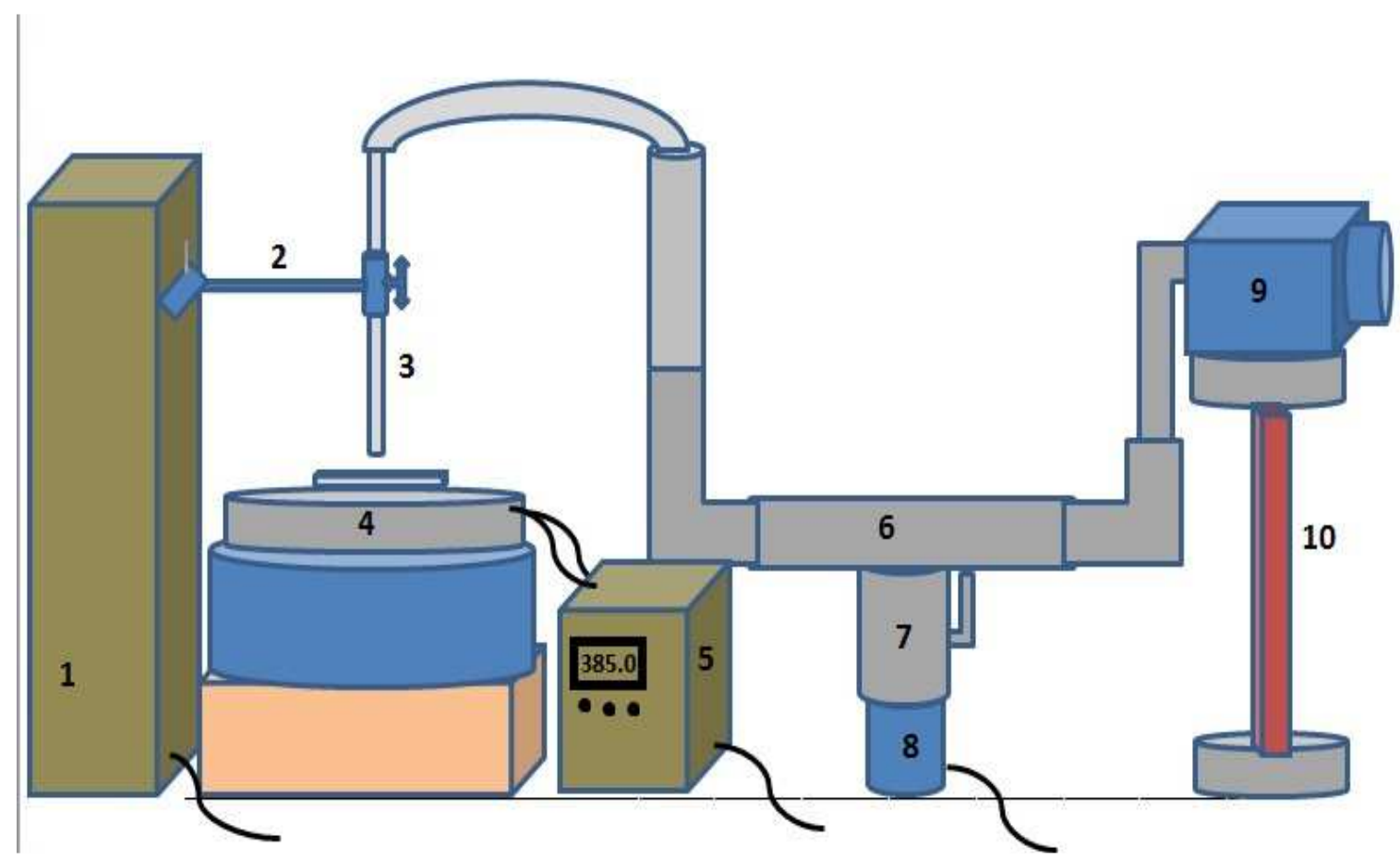

Figure 1: Ultrasonic 1.7 MHz Vapour Generator System for Thin Film Development. (1) Mist Delivery Arm Controller, (2) Mist Delivery Tube Holder, (3) Mist Delivery Glass Pipe, (4) Heater, (5) Temperature Measuring System and Controller, (6) PVC Pipe System to Carry Mist (7) Solution Holder, (8) Ultra Sonic Vapourizer, (9) Air Pump, (10) Air Pump Stand.

\subsection{Preparation of Solution}

Stock solutions of $0.1 \mathrm{M}$ of Cadmium chloride in $0.1 \mathrm{M}$ ethylene diamine and $0.1 \mathrm{M}$ boric acid $\left(\mathrm{H}_{3} \mathrm{BO}_{4}\right)$ was prepared in two separate volumetric flasks of $100 \mathrm{ml}$ using double distilled water and working solution was prepared by mixing $9.0 \mathrm{ml}$ volume of cadmium chloride solution with $1.0 \mathrm{ml}$ volume of boric acid solution for $10 \%$ boron doped cadmium sulphide thin film. It was further diluted to $50 \mathrm{ml}$ by double distilled water. Diluted solution was loaded into low cost ultrasonic vapour generator.

\subsection{Thin Film Generation}

The generated vapours were deposited at $425^{\circ} \mathrm{C}$ on a grease free cleaned neutral glass slide. For other dilutions, solutions were prepared as given in table 1 .

Table 1

\begin{tabular}{|c|c|c|}
\hline Boron \% & CdCl $_{2}$ Solution & Boric Acid Solution \\
\hline 0 & 10.0 & 0.0 \\
\hline 1.5 & 9.85 & 0.15 \\
\hline 2.5 & 9.75 & 0.25 \\
\hline 7.5 & 9.25 & 0.75 \\
\hline 10.0 & 9.00 & 1.00 \\
\hline 12.5 & 8.75 & 1.25 \\
\hline
\end{tabular}




\section{RESULTS AND DISCUSSIONS}

Boron doped CdS films was deposited on neutral glass substrate whose XRD pattern is shown in figure 2. Comparison of XRD pattern of CdS and boron doped CdS films with the standard from PDF-2, database 1990 JCPDS-International center for diffraction data, 80-0006 and 77-2307 confirm that the thin film was of CdS. In table 2, each film exhibited one prominent peak related to $\left(\begin{array}{lll}0 & 0 & 2\end{array}\right)$ and other smaller peaks.

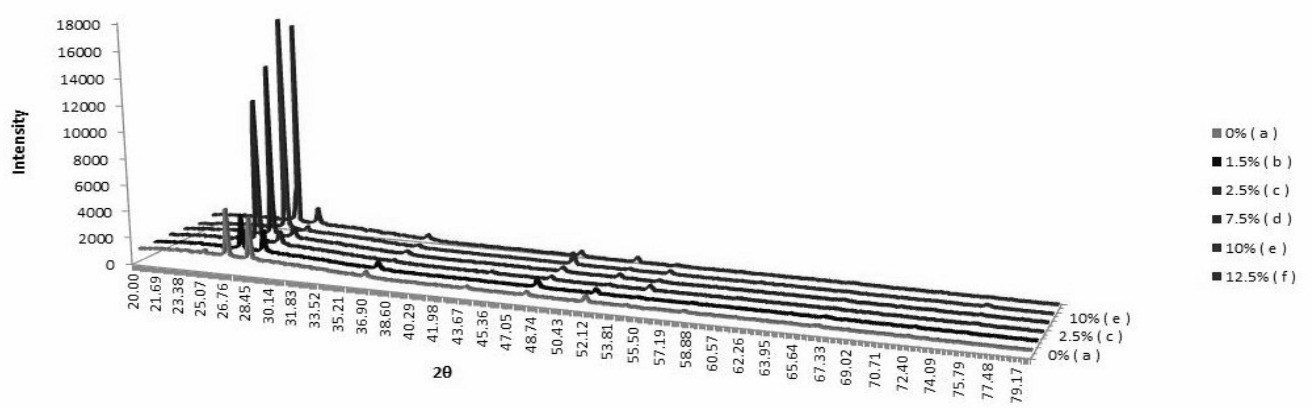

Figure 2: XRD of CdS and Boron Doped CdS.

\begin{tabular}{|l|c|c|c|c|c|c|c|}
\hline \multicolumn{7}{|c|}{ Table 2: XRD of CdS and Boron Doped CdS } \\
\hline XRD of & $\mathbf{( 1 0 ~ 0 )}$ & $\mathbf{( 0 ~ 0 ~ 2 )}$ & $\mathbf{( 1 0 ~ 1 )}$ & $\mathbf{( 1 ~ 1 0 )}$ & $\mathbf{( 1 0 ~ 3 )}$ & $\mathbf{( 1 ~ 1 ~ 2 )}$ & Band Gap(Cal) \\
\hline CdS(Std) & 24.91 & 26.66 & 28.33 & 43.91 & 48.12 & 52.11 & \\
\hline CdS & 24.97 & 26.66 & 28.35 & 43.86 & 47.94 & 52.01 & 2.420 \\
\hline $1.5 \%$ B & & 26.66 & 28.35 & & 47.94 & 51.92 & 2.430 \\
\hline $2.5 \%$ B & & 26.86 & 28.48 & 43.28 & 48.01 & & 2.435 \\
\hline $7.5 \%$ B & & 26.86 & 28.55 & & 48.01 & 52.1 & 2.435 \\
\hline $10.0 \%$ B & & 26.86 & 28.45 & & 48.04 & & 2.445 \\
\hline $12.5 \%$ B & & 26.86 & 28.35 & & & 52.01 & 2.445 \\
\hline
\end{tabular}

$\mathrm{CdS}$ films exist in two crystalline forms, the hexagonal phase and the cubic phase. The preferred orientation of $\left(\begin{array}{lll}0 & 0 & 2\end{array}\right)$ in boron doped CdS films may be due to the controlled nucleation process at $425^{\circ} \mathrm{C}$. However, there was a shift in $2 \theta$ value of $7.5 \%, 10.0 \%, 12.5 \%$ boron doping in CdS films, this may be attributed to the doping of boron. XRD analysis proved that there was no change in crystal orientation due to boron doping and ultrasonic vaporizing system. 


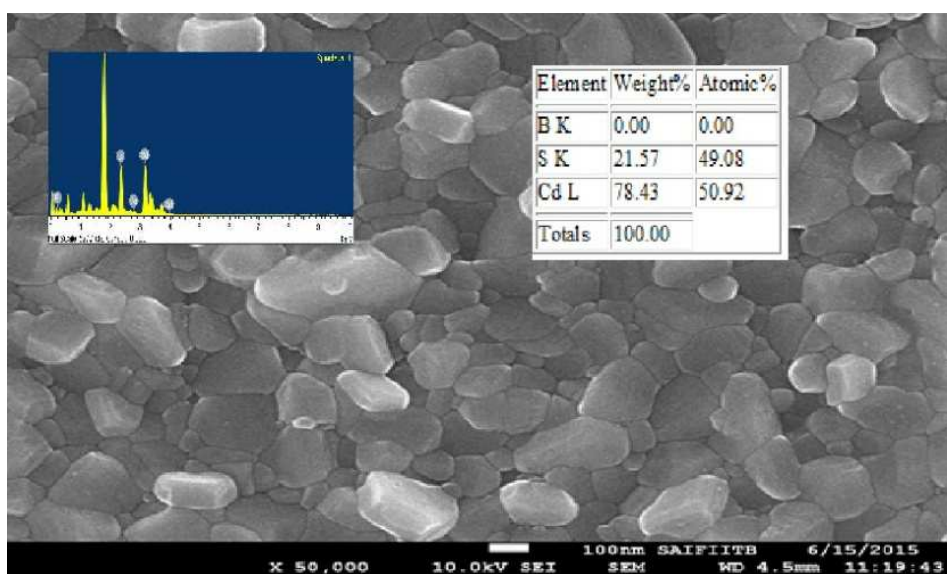

Figure 3: SEM Micrograph of 10\% Boron Doped CdS Thin Film.

Figure 3 shows the SEM micrographs of 10.0\% boron doped CdS films. SEM micrograph shows dense layer small crystals of the size $70 \mathrm{~nm}$ and few large ones are of approximately $250 \mathrm{~nm}$ in size are embedded on the surface.

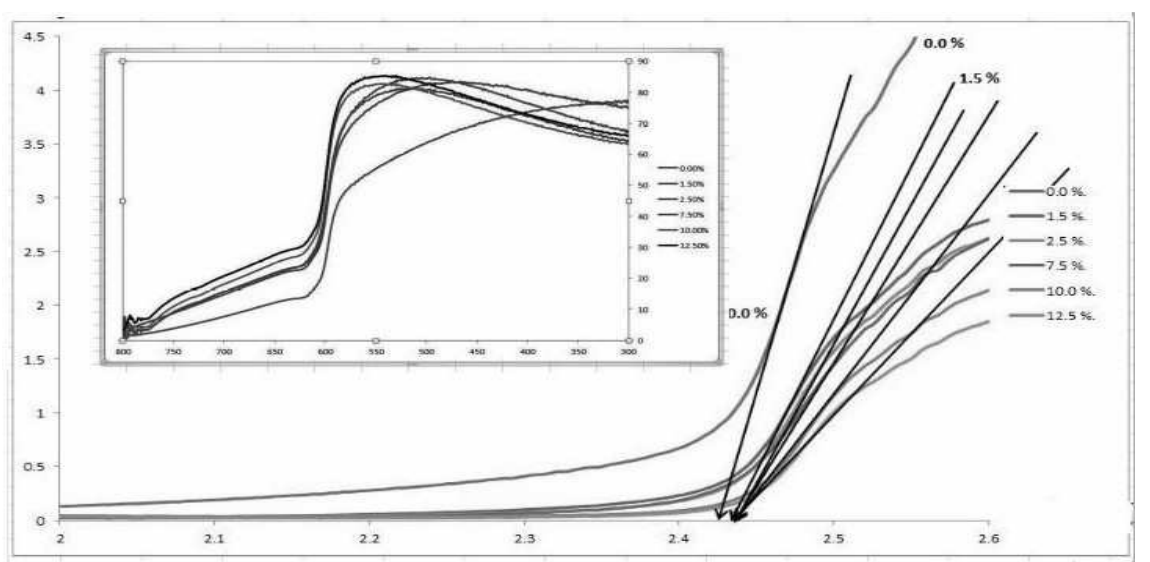

Figure 4: Optical Spectrum Wavelength (nm Versus Transmittance \%) and (ahv)2 versus eV (hv) Optical Band Gap Obtained.

Optical spectral transmittance of boron doped CdS showed almost similar results as that of plain CdS thin film. Deviation observed was not significant when compared the values of optical band gap energy as shown in table 2 and figure 4 .

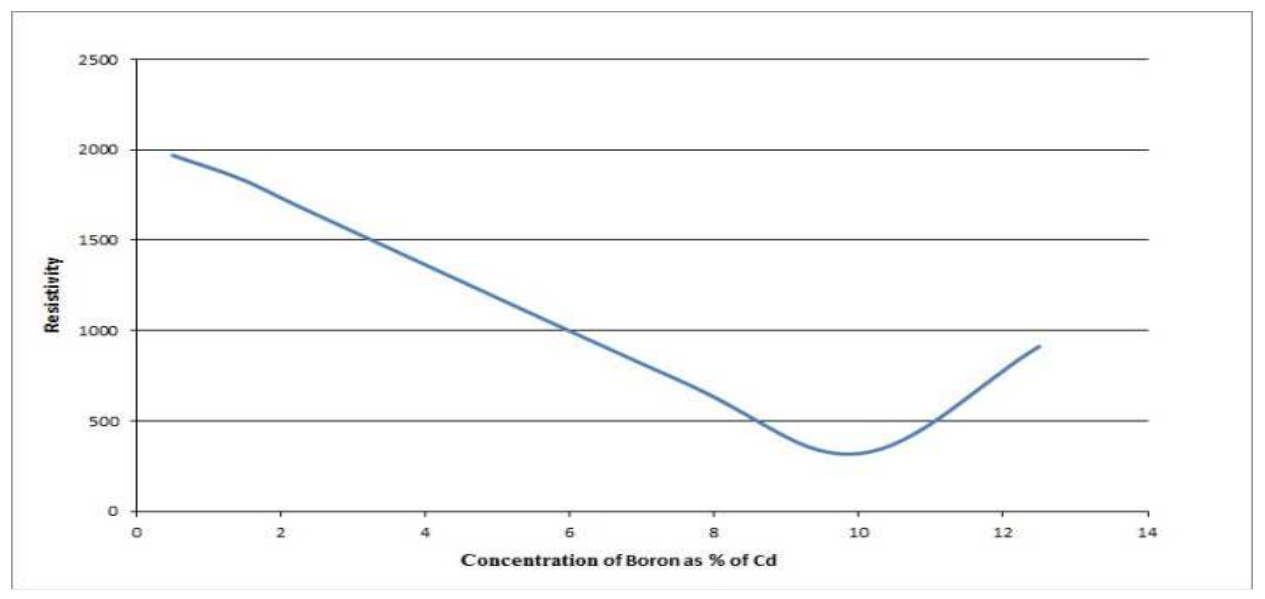

Figure 5: Resistivity verses Boron Concentration. 
Boron doping into CdS films has been shown to have decreasing effect on the resistivity as shown in the graph of figure 5. Ten percent boron doping had shown lowest resistivity when measured in presence of sunlight. In this process of formation of thin film, resistivity remains low. Band gap calculation showed that there was no much variation. Low resistivity was reported by Lee et al. (2003). Thus ultrasonic vapour generated vapour pyrolysis proved to be a better method to obtained very good quality film for solar cell window layer. Higher solar efficiency was reported by Hagiwara et al. (2001) due to boron doping.

\section{CONCLUSIONS}

Low resistivity due to boron doping in the CdS thin film will help in improving the solar cell efficiency. Morphological and XRD analysis suggest that ultrasonic system can be used for developing window layer of CdS in solar cell construction.

\section{REFERENCES}

1. J.H. Lee, J.S. Yia, K.J. Yang, J.H. Park, R.D. Oh, Electrical and optical properties of boron doped CdS thin films prepared by chemical bath deposition, Thin Solid Films 431 -432 (2003) 344-348, doi:10.1016/S0040-6090(03)00153-6, ISSN: S00406090 .

2. G. Sasikala, R. Dhanasekaran, C. Subramanian, Thin Solid Films 302 (1997) 71.

3. Akram, A. S., Reddy, K. J., Madhu, B., \& Reddy, P. L. Effect of Screen Mesh Wick And Al2O3 Nanofluid Concentration on Circular Heat Pipe Performance.

4. Lekha Verma, Dipali Soren, Sandhya Pillai, Prashant Shrivastava, Different Properties of CdS nanocrystalline material: A Review, I.J. Recent Engineering Research and Devp. (IJRERD) Vol 02 (3), 1-4, ISSN: 2455-8761.

5. R.S. Meshram, B.M. Suryavanshi and R.M. Thombre, Structural and optical properties of CdS thin films obtained by spray pyrolysis, A. A. Science Research, 2012, 3 (3):1563-1571, ISSN: 0976-8610.

6. Usikalu, M. R., Shittu, A. H., \& Obafemi, L. N. (2018). Construction of an Intelligent and Efficient Light Control System. International Journal of Mechanical and Production Engineering Research and Development, 8(4), 1025-1034.

7. M.Y. Reddy and N.V.M. Prasad, Properties of CdS Chemically Deposited thin films on the Effect of Ammonia Concentration, IOSR J. of Applied Physics, 4/4 (2013), 01-07, e-ISSN: 2278-4861.

8. Wug-Dong Park, Optical Constants and Dispersion Parameters of CdS Thin Film Prepared by Chemical Bath Deposition, T.E.E.Materials, 13/4, 196-199, 2012, DOI: 10.4313/TEEM.2012.13.4.196, pISSN: 1229-7607 eISSN: 2092-7592.

9. Inegbenebor, A. I., Mordi, R. C., Idowu, A. O., Siyanbola, T. O., Akanle, B., Evbuoma, I. K., \& Inegbenebor, A. O. (2018). Consequences of the Activities of a Nigerian Cement Industry on the Environment. International Journal of Applied and Natural Sciences (IJANS), 7(4), 67-74.

10. Y. Hagiwara, T. Nakada, A. Kunioka, Improved Jsc in CIGS thin film solar cells using a transparent conducting ZnO:B window layer, Solar Energy Materials \& Solar Cells 67 (2001) 267)271, PII: S0927-0248(00)00291-9,ISSN: 0927-0248.

11. Zanje S.S., Dhanawade R.N., Electrical Properties of CDS Thin Films by Vacuum Evaporation Deposition, I.J. Science and Research (IJSR),4/3, 2015, 1708-1710, ISSN (Online): 2319-7064. 


\section{AUTHOR'S PROFILE}

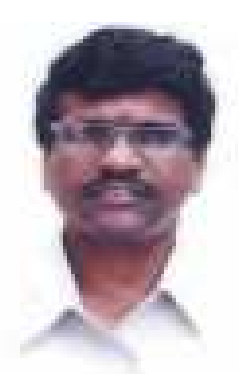

Dr. GBKS Prasad Professor of Biochemistry Jiwaji University, Gwalior Academic Qualifications Ph.D Nagpur University 1988 M.Sc Sri Venkateswara University 1981 B.Sc Andhra University 1979 Fellowships \& Visits outside India on various academic assignments 1. Commonwealth Fellowship for Postdoctoral Research at Liverpool School of Tropical Medicine, Liverpool, UK, 1998- 2000 2. Texas University Health Science Centre at Houston, USA under Indo-US Collaboration in Science \& Technology program. 3. Imperial college of Science \& Technology, London 4. World Health Organizaiton, Geneva, Activities in nut shell Dr. Prasad possess about 24 yrs of teaching and research experience in the field of Diagnostics and biomedical research including evaluation of drugs and is currently leading a research team of nine junior researchers. Research projects funded by various Public and Private agencies, on various aspects of Diabetes mellitus including two on evaluation of two drug preparations of indigenous systems of medicine are underway. Dr. Prasad's group published research papers in peer reviewed National and International journals. He co-authored two text books viz., 'Molecular Diagnostics: Promises \& Possibilities' published in 2010 by Springer, USA and Microbes: Concepts and Applications published by Wiley-Blackwell, 2012. The laboratory runs a week end 'Diabetes clinic' in association with Ayurvedic physicians. Ongoing Research Projects Evaluation of preventive and therapeutic potential of an ayurvedic anti-diabetic drug preparations in collaboration with M/S Deendayal aushadhalaya Pvt.Ltd, Gwalior Evaluation of 'Trifala' as an anti-diabetic drug in prevention and management of human type II diabetes mellitus and diabetes complications Therapeutic and nutritional potential of Spirulina maxima cultivated under electromagnetic field and different light intensities in an air-lift photobioreactor. Evaluation of red cell antigen specific monoclonal / polyclonal antibodies immobilized on different solid supports for their longevity as agglutinins' Evaluation of anti-hyperglycemic and anti-oxidant properties of natural herbals and their products. Evaluation of Spirulina maxima and Spirulina platensis as catalysts in bio fuel cell. Evaluation of neutraceutical potential of bottle gourd extract, honey from different floral sources. Evaluation of natural and synthetic preparations for anti-microbial activities against wound associated pathogens. Evaluation of certain ayurvedic formulations of therapeutic importance for their toxicity in vivo. The research projects are running in collaboration with scientists of DRDE, KRJ (PG) College and M/S Deendayal Aushadhi Pvt. Ltd. and are supported by different funding agencies. Research Supervisor Supervised about 20 Ph.D dissertations, several M.Phil and M.Sc dissertations. Research Training: Research training is imparted to PG students of other Universities in the form of short term research projects 5-6 months duration in every academic year. Publications: a. Research papers : 105 (Peer reviewed journals) b. Technical reports : 04 c. Popular articles : 01 d. Books : 02 e. Biotechnology booklet for MBA (CSM) 


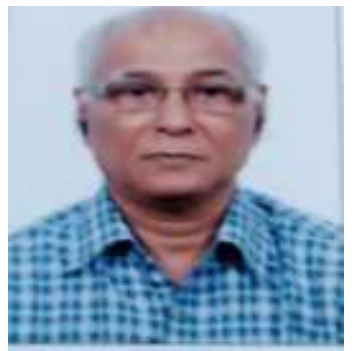

Mr. Dinesh Borole, did his M.Sc.(Biophysics) from Cancer Research Institute, Tata Memorial centre Mumbai, Mumbai University, Mumbai, Maharashtra in 1981. I worked in Cancer Research Institute, Mumbai as research fellow in a project Semecarpus anacardium as an anticancer drug under the leadership of Dr. M. P. Chitnis. I had also worked as a Lecturer in Institute of Science, Aurangabad. Thereafter I worked for Varian, Finnigan Mat as an application engineer. I have also contributed few chapters towards a book “Text book of Medical Biochemistry”(CBS publication), ISBN: 978-81-2391566-1 by Kapoor and kumudini. Thereafter I developed interest in computer programming and worked in software organisations. After 9/11 world trade center event I switched over to Research field in solar cell construction using chlorophyll and natural dyes in Jiwaji University on project

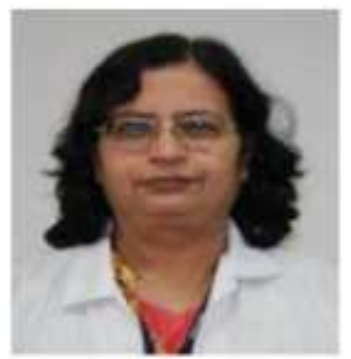

Dr. Kumudini Borole (nee Parkhe K.), Professor of Biochemistry Dr. Kumudini Borole did her M.Sc.(Biochemistry) from RTM Nagpur University, Nagpur, Maharashtre in 1984. She joined MGIMS, Sewagram, Wardha in Biochemistry Department as research fellow and completed her PhD in Feb 1991. She also worked as postdoctoral fellow in Center for cellular and Molecular Biology (CCMB). She is a recipient of A Krishnamurty award of a society of Biological Chemist of India. She has 10 research publications in National and International indexed journals. Her areas of interests are Immunodiagnosis, molecular biology and nanoscience, To her credit she has "Text book of Medical Biochemistry"(CBS publication), ISBN: 978-81-239-1566-1 and "Hand book of Biochemistry" for students, She also contributed one chapter in Communication skills book of DMIMS. In addition to this she also has two e-books to her credit Medical MCQs, ISBN:978-13-122-1319-7. , Anatomy Physiology and Biochemistry MCQ’s, ISBN:978-13-122-2990-7.)She is recognized faculty in Maharashtra university health sciences, and also faculty for advance course in medical education.

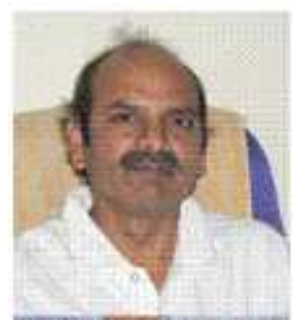

Dr. P. Rajaram did his M.Sc. from Kakataiya University Warangal (AP) in 1977. Subsequently, he joined IIT, New Delhi for M.Tech. in Materials Science. He completed the M.Tech. in 1980. In Continuation, he joined Ph.D. He was awarded 
Ph.D. for his work on Thin Films in 1984. Thereafter, he visited Collorado, USA in 1988 to obtain training on Amorphous Silicon material. He joined this department as Lecturer in 1989. He was promoted to the post of Reader and Professor in 2006. His areas of interests are Condensed matter Physics, Materiel Science, Thin films and Optoelectronic. He has supervised number of students for their dissertation at M.Phil. level. He has also guided students for their Ph.D. degree and till now four students have been awarded Ph.D. under his supervision. Dr. Rajaram has quite long experience of working on Vacuum Coating unit; Computer controlled Potentiostat and Transmission Electron Microscope. He has developed low cost CVD set-up for deposition of Tin Oxide and Zinc Oxide thin films. He has published more than 20 research papers in national and international journals. He has also attended number of seminars / symposiums / conferences and presented more than 50 research papers. 